\title{
Thiazolopyridines Improve Adipocyte Function by Inhibiting 11 Beta-HSD1 Oxoreductase Activity
}

\author{
Thirumurugan Rathinasabapathy, ${ }^{1}$ Kimberly Marie Palatini Jackson, ${ }^{2,3}$ \\ Yiwen Thor, ${ }^{3}$ Ayuba Sunday Buru, ${ }^{1}$ Debora Esposito, ${ }^{2,4} \mathrm{Xu} \mathrm{Li}^{2,5}$ Mallikarjuna Rao Pichika, ${ }^{1}$ \\ Ahmad Sazali Hamzah, ${ }^{6}$ and Slavko Komarnytsky, \\ ${ }^{1}$ Department of Pharmaceutical Chemistry, School of Pharmacy, International Medical University, 126, Jalan Jalil Perkasa 19, \\ Bukit Jalil, 57000 Kuala Lumpur, Malaysia \\ ${ }^{2}$ Plants for Human Health Institute, North Carolina State University, North Carolina Research Campus, 600 Laureate Way, \\ Kannapolis, NC 28081, USA \\ ${ }^{3}$ Department of Food, Bioprocessing, and Nutrition Sciences, North Carolina State University, 400 Dan Allen Drive, \\ Raleigh, NC 27695, USA \\ ${ }^{4}$ Department of Animal Science, North Carolina State University, 120 Broughton Drive, Raleigh, NC 27695, USA \\ ${ }^{5}$ Department of Plant and Microbial Biology, North Carolina State University, 100 Derieux Place, Raleigh, NC 27695, USA \\ ${ }^{6}$ Center for Synthesis and Chemical Biology, Institute of Science, Universiti Teknologi MARA, 40450 Shah Alam, \\ Selangor Darul Ehsan, Malaysia
}

Correspondence should be addressed to Slavko Komarnytsky; komarnytsky@ncsu.edu

Received 25 December 2016; Revised 26 February 2017; Accepted 12 March 2017; Published 29 March 2017

Academic Editor: Shengmin Sang

Copyright (C) 2017 Thirumurugan Rathinasabapathy et al. This is an open access article distributed under the Creative Commons Attribution License, which permits unrestricted use, distribution, and reproduction in any medium, provided the original work is properly cited.

\begin{abstract}
Background. Glucocorticoid excess has been linked to clinical observations associated with the pathophysiology of metabolic syndrome. The intracellular glucocorticoid levels are primarily modulated by $11 \beta$-hydroxysteroid dehydrogenase type 1 (11 $\beta$-HSD1) enzyme that is highly expressed in key metabolic tissues including fat, liver, and the central nervous system. Methods. In this study we synthesized a set of novel tetrahydrothiazolopyridine derivatives, TR-01-4, that specifically target 11 $\beta$-HSD1 and studied their ability to interfere with the glucocorticoid and lipid metabolism in the 3T3-L1 adipocytes. Results. Based on the docking model and structure-activity relationships, tetrahydrothiazolopyridine derivatives TR- 02 and TR-0 4 showed the highest potency against $11 \beta$ HSD1 by dose-dependently inhibiting conversion of cortisone to cortisol ( $\mathrm{IC}_{50}$ values of $1.8 \mu \mathrm{M}$ and $0.095 \mu \mathrm{M}$, resp.). Incubation of fat cells with 0.1-10 $\mu \mathrm{M}$ TR-01-4 significantly decreased cortisone-induced lipid accumulation in adipocytes and suppressed 11 $\beta$ HSD1 mRNA expression. Observed reduction in adipocyte fat stores could be partially explained by decreased expression levels of adipogenic markers (PPAR- $\gamma$, aP2) and key enzymes of lipid metabolism, including fatty acid synthase (FAS), hormone sensitive lipase (HSL), and lipoprotein lipase (LPL). Conclusions. The tetrahydrothiazolopyridine moiety served as an active pharmacophore for inhibiting $11 \beta$-HSD1 and offered a novel therapeutic strategy to ameliorate metabolic alterations found in obesity and diabetes.
\end{abstract}

\section{Introduction}

The worldwide surge in prevalence of obesity and associated type 2 diabetes mellitus increases the need for novel preventive and therapeutic strategies as stated by the World Health Organization [1]. The metabolic disorders are no longer confined to residents of affluent industrialized Western countries (i.e., United States, where about $30 \%$ of adults are overweight and another 30\% are obese) [2] but become more widespread in the developing world, including Malaysia, where 30\% and $15 \%$ of adults are overweight and obese, respectively [3].

High levels of circulating glucocorticoids, as seen in Cushing syndrome, promote hyperphagia, central obesity, and insulin resistance [4]. In the majority of obese subjects, however, circulating glucocorticoids do not correlate with obesity, blood glucose, or insulin levels due to increased cortisol clearance [5] and tissue-specific metabolism by 
$11 \beta$-hydroxysteroid dehydrogenases (11 $\beta$-HSDs) [6]. Intracellular regeneration of active steroids cortisol from cortisone (in humans) and corticosterone from 11-dehydrocorticosterone (in rodents) is achieved through $11 \beta$-HSD type 1 $(11 \beta$-HSD1), a lower-affinity $\operatorname{NADP}(\mathrm{H})$-dependent enzyme that acts as oxoreductase in tissues with high sensitivity to glucocorticoids [7]. The opposing dehydrogenase activity of $11 \beta$-HSD1 (conversion of cortisol to cortisone) becomes evident only in cell culture and tissue homogenates or upon purification due to decrease of ER luminal cofactor $\operatorname{NADP}(\mathrm{H})$ generated by hexose-6-phosphate dehydrogenase [8].

Several studies have highlighted $11 \beta$-HSD1 as a novel therapeutic target in metabolic syndrome. $11 \beta$-HSD1 knockout mice had low intracellular glucocorticoid levels and were protected from obesity, diabetes, and dyslipidemia $[9,10]$. Conversely, transgenic overexpression of $11 \beta$-HSD1 in white adipose tissue resulted in elevated intracellular glucocorticoid levels, central obesity, insulin resistance, hyperglycemia, and dyslipidemia in mice [11]. A number of structural classes of $11 \beta$-HSD1 inhibitors have been described in the literature [12], including the benzothiazole class of compounds which are bioisostere to tetrahydrothiazolopyridine [13] and are frequently reported as dipeptidyl peptidase IV inhibitors. In preclinical studies with C57BL/6J mice fed high fat diet, the beneficial effects of $11 \beta$-HSD1 inhibition were observed, including reduced body weight, food intake, and fasting glucose and insulin levels [14]. However, phase IIb clinical trials with existing $11 \beta$-HSD1 inhibitors resulted in modest improvements of glucose homeostasis in type 2 diabetic subjects $[15,16]$. For example, salicylates administered at $50 \mathrm{mg} / \mathrm{kg} /$ day for 2 weeks reduced $11 \beta$-HSD1 mRNA levels in human subcutaneous fat, and a similar effect was observed in fully differentiated human SGBS adipocytes in the dose range of $10-100 \mu \mathrm{M}$ [17].

Given the public health significance of metabolic disorders and the observation that past therapeutic approaches have not met with success in addressing this issue, new strategies are clearly needed. We therefore explored a novel class of $11 \beta$-HSD1 inhibitors based on the tetrahydrothiazolopyridine skeleton. Previously, several members of this class of compounds were reported to inhibit phosphatidylinositol 3kinase [18]. Here, we report on the synthesis of four TR14 derivatives, their inhibitory effects on $11 \beta$-HSD1 activity, adipocyte differentiation, and expression of key adipose genes associated with lipid metabolism and insulin resistance.

\section{Materials and Methods}

2.1. Chemicals and Analytical Methods. All chemicals and solvents (anhydrous and ACS grade) were purchased from Sigma-Aldrich (Saint Louis, MO) unless specified otherwise. Structures and purity (>95\%) of all compounds were confirmed by LC-MS using Bruker (Billerica, MA) Avance Electrospray Ionization quadrupole time-of-flight mass detector (ESI-Q-TOF-MS) with MS/MS (Triple quadrupole) interface, using Agilent Technologies (Santa Clara, CA) Extend C18 reverse phase column $(250 \mathrm{~mm} \times 4.6 \mathrm{~mm}, 5.0 \mu \mathrm{m}) .{ }^{1} \mathrm{H}$ NMR and ${ }^{13} \mathrm{C}$ NMR spectra were recorded on Bruker Avance 300, $500 \mathrm{MHz}$ NMR stations.
2.2. Synthesis of 2-Amino-5-benzyl-4,5,6,7-tetrahydrothiazolo[5,4-C]pyridine (TR-01). 2-Amino-5-benzyl-4,5,6,7-tetrahydrothiazolo[5,4-c]pyridine was synthesized using a previously reported procedure with some modifications [19]. 1Benzyl-4-piperidone $(1.0 \mathrm{~g}, 5.3 \mathrm{mM})$ was dissolved in $30 \mathrm{ml}$ of cyclohexane. To this solution, pyrrolidine $(0.4 \mathrm{~g}, 5.5 \mathrm{mM})$ and p-toluenesulphonic acid (catalytic quantity) were added and refluxed for $2.5 \mathrm{~h}$ using Dean-Stark trap. Then, the reaction mixture was cooled to room temperature and filtered and the filtrate was concentrated to dryness in vacuo. The formed residue was dissolved in $25 \mathrm{ml}$ of dry methanol; sulphur $\left(\mathrm{S}_{8}, 0.17 \mathrm{~g}, 0.66 \mathrm{mM}\right)$ was added at once and the reaction mixture was stirred for $10 \mathrm{~min}$ at room temperature. Then, the reaction mixture was cooled to $0^{\circ} \mathrm{C}$, cyanamide $(0.22 \mathrm{~g}, 5.3 \mathrm{mM})$ in $5 \mathrm{ml}$ of dry methanol was added slowly in dropwise manner, and the reaction was continued for $5 \mathrm{~h}$ at the same temperature. After completion of the reaction, the mixture was filtered and concentrated to obtain a crude compound. TR-01 was chromatographed over silica gel with dichloromethane/methanol $(99: 1)$ as eluent, yielding $51.2 \%$. The purity of the compound was confirmed by TLC using $\mathrm{CHCl}_{3} / \mathrm{CH}_{3} \mathrm{OH}\left[(95: 5) ; R_{f}=0.78\right]$, ESI-Q-TOF-MS: $(m / z)$ $246.1[\mathrm{M}+\mathrm{H}]$ and NMR spectra; ${ }^{1} \mathrm{H}$ NMR $(500 \mathrm{MHz}$, DMSO- $\left.\mathrm{d}_{6}\right) \delta=2.48(\mathrm{t}, 2 \mathrm{H}, \mathrm{J}=6.0 \mathrm{~Hz}), 2.70(\mathrm{t}, 2 \mathrm{H}, \mathrm{J}=6.0 \mathrm{~Hz})$, 3.53 (s, 2H), 3.64 (s, 2H), 6.69 (s, 2H, NH 2$), 7.25$ (dt, 1H, J $=4.0 \mathrm{~Hz}), 7.34(\mathrm{~m}, 4 \mathrm{H}) ;{ }^{13} \mathrm{C} \mathrm{NMR}\left(125 \mathrm{MHz}, \mathrm{DMSO}-\mathrm{d}_{6}\right) \delta=$ 26.9, 50.0, 50.3, 61.2, 112.6, 127.4, 128.7, 129.2, 139.0, 143.9, 166.6.

2.3. Synthesis of $\mathrm{N}$-(5-Benzyl-4,5,6,7-tetrahydrothiazolo[5,4c]pyridine-2-yl)-3-(4-chlorophenyl)-2-cyanoacrylamide (TR02). The intermediate cyanoester compound was synthesized by Knoevenagel condensation method [20] in which 4-chlorobenzaldehyde $(1.0 \mathrm{~g}, 7.1 \mathrm{mM})$ was dissolved in $25 \mathrm{ml}$ of methanol. tert-Butyl cyanoacetate $(1.0 \mathrm{~g}, 7.1 \mathrm{mM})$ and piperidine ( 5 drops) were added and the mixture was refluxed for $45 \mathrm{~min}$. After the completion of the reaction, $100 \mathrm{ml}$ of ice-cold water was added, and the formed precipitate was collected by filtration, recrystallized from ethanol-water to give tert-butyl-3-(4-chlorophenyl)-2-cyanoacrylate. This ester compound was dissolved in $10 \mathrm{ml}$ of dichloromethane, to which $10 \mathrm{ml}$ of trifluoroacetic acid was added and stirred at room temperature for $1 \mathrm{~h}$. The reaction mixture was evaporated in vacuo; the solid was triturated with water, filtered, and dried to give 3-(4-chlorophenyl)-2-cyanoacrylic acid. The purity of this compound was confirmed by TLC using $\mathrm{CHCl}_{3} / \mathrm{CH}_{3} \mathrm{OH}\left[(90: 10) ; R_{f}=0.4\right]$ and melting point (m.p. $\left.192^{\circ} \mathrm{C}\right)$. The compound $(0.5 \mathrm{~g}, 2.4 \mathrm{mM})$ was further dissolved in $30 \mathrm{ml}$ of dichloromethane, EDCI (0.55 g, $2.9 \mathrm{mM})$, HOBt $(0.39 \mathrm{~g}, 2.9 \mathrm{mM})$, and DIPEA $(0.69 \mathrm{~g}, 5.3 \mathrm{mM})$ and stirred for $1 \mathrm{~h}$ at room temperature. Then TR-01 $(0.59 \mathrm{~g}$, $2.4 \mathrm{mM}$ ) was added, and the stirring was continued at same temperature for $24 \mathrm{~h}$. The reaction mixture was washed with water, saturated $\mathrm{NaHCO}_{3}$, and brine and concentrated by drying over anhydrous $\mathrm{Na}_{2} \mathrm{SO}_{4}$. The crude compound was chromatographed over silica gel using dichloromethane/methanol $(95: 5)$ as eluent, yielding $47.6 \%$ of titled TR-02. The purity of the compound was confirmed by TLC using $\mathrm{CHCl}_{3} / \mathrm{CH}_{3} \mathrm{OH}\left[(95: 5) ; R_{f}=0.65\right]$ and NMR 
spectra; ${ }^{1} \mathrm{H}$ NMR $\left(300 \mathrm{MHz}, \mathrm{DMSO}-\mathrm{d}_{6}\right) \delta=2.62(\mathrm{t}, 2 \mathrm{H}, \mathrm{J}=$ $5.1 \mathrm{~Hz}), 2.79(\mathrm{t}, 2 \mathrm{H}, \mathrm{J}=5.1 \mathrm{~Hz}), 3.50(\mathrm{~s}, 2 \mathrm{H}), 3.70(\mathrm{~s}, 2 \mathrm{H}), 7.28$ $(\mathrm{t}, 1 \mathrm{H}, \mathrm{J}=3.9 \mathrm{~Hz}, \mathrm{ArH}), 7.33(\mathrm{~m}, 4 \mathrm{H}), 7.65(\mathrm{~d}, 2 \mathrm{H}, \mathrm{J}=8.4 \mathrm{~Hz})$, $8.00(\mathrm{~d}, 2 \mathrm{H}, \mathrm{J}=8.4 \mathrm{~Hz}), 8.34(\mathrm{~s}, 1 \mathrm{H}), 13.19$ (s, 1H, NH).

2.4. Synthesis of 2-Amino-4,5,6,7-tetrahydrothiazolo[5,4-c]pyridine (TR-03). 2-Amino-4,5,6,7-tetrahydrothia-zolo[5,4c]pyridine was synthesized using a previously reported procedure [19]. 1-tert-Butoxycarbonyl-4-piperidone (1.0 g, $5.0 \mathrm{mM}$ ) was dissolved in $30 \mathrm{ml}$ of cyclohexane. To this solution, pyrrolidine $(0.38 \mathrm{~g}, 5.3 \mathrm{mM})$ and p-toluenesulphonic acid (catalytic quantity) were added and refluxed for $2.5 \mathrm{~h}$ using Dean-Stark trap. Then, the reaction was cooled to room temperature and filtered and the filtrate was concentrated to dryness in vacuo. The formed residue was dissolved in $25 \mathrm{ml}$ of dry methanol; sulphur $\left(S_{8}, 0.16 \mathrm{~g}, 0.63 \mathrm{mM}\right)$ was added at once and the reaction mixture was stirred for $10 \mathrm{~min}$ at room temperature. Then, the reaction mixture was cooled to $0^{\circ} \mathrm{C}$, cyanamide $(0.21 \mathrm{~g}, 5.0 \mathrm{mM})$ in $5 \mathrm{ml}$ of dry methanol was added slowly in dropwise manner, and the reaction was continued for $5 \mathrm{~h}$ at the same temperature. After completion of the reaction, the mixture was filtered and concentrated to get the crude TR-03a. TR-03a was further chromatographed over silica gel with dichloromethane/methanol $(98: 2)$ as eluent, yielding $73.4 \%$. The purity of the compound was confirmed by TLC using $\mathrm{CHCl}_{3} / \mathrm{CH}_{3} \mathrm{OH}$ [(95:5); $\left.R_{f}=0.72\right]$, ESI-Q-TOF-MS: $(m / z) 256.3[\mathrm{M}+\mathrm{H}]$, and NMR spectra; ${ }^{1} \mathrm{H}$ NMR $\left(500 \mathrm{MHz}, \mathrm{DMSO}-\mathrm{d}_{6}\right) \delta=1.41(\mathrm{~s}, 9 \mathrm{H})$, $2.43(\mathrm{t}, 2 \mathrm{H}, \mathrm{J}=6.0 \mathrm{~Hz}), 3.56(\mathrm{t}, 2 \mathrm{H}, \mathrm{J}=5.5 \mathrm{~Hz}), 4.29(\mathrm{~s}, 2 \mathrm{H})$, $6.80\left(\mathrm{~s}, 2 \mathrm{H}, \mathrm{NH}_{2}\right)$.

The confirmed TR-03a was then treated with $1: 1$ ratio of dichloromethane and trifluoroacetic acid and stirred for $1 \mathrm{~h}$ at room temperature. The reaction mixture was concentrated and washed with water and diethyl ether. Then the reaction mixture was dissolved in dichloromethane, washed with water and brine, and concentrated by drying over anhydrous $\mathrm{Na}_{2} \mathrm{SO}_{4}$ to obtain TR-03. The purity of the compound was confirmed by NMR spectra; ${ }^{1} \mathrm{H}$ NMR $\left(300 \mathrm{MHz}, \mathrm{DMSO}-\mathrm{d}_{6}\right)$ $\delta=2.32(\mathrm{t}, 2 \mathrm{H}, \mathrm{J}=5.4 \mathrm{~Hz}), 2.86(\mathrm{t}, 2 \mathrm{H}, \mathrm{J}=5.4 \mathrm{~Hz}), 3.59(\mathrm{~s}$, $2 \mathrm{H}), 6.63$ (s, 2H, $\mathrm{NH}_{2}$ ).

2.5. Synthesis of 2-Amino-5-methyl-4,5,6,7-tetrahydrothiazolo[5,4-c]pyridine (TR-04). 2-Amino-5-methyl-4,5,6,7-tetrahydrothiazolo[5,4-c]pyridine was synthesized using a previously reported procedure [19]. 1-Methyl-4-piperidone $(1.0 \mathrm{~g}, 8.84 \mathrm{mM})$ was dissolved in $30 \mathrm{ml}$ of cyclohexane. To this solution, pyrrolidine $(0.66 \mathrm{~g}, 9.3 \mathrm{mM})$ and p-toluenesulphonic acid (catalytic quantity) were added and refluxed for $2.5 \mathrm{~h}$ using Dean-Stark trap. Then, the reaction was cooled to room temperature and filtered, and the filtrate was concentrated to dryness in vacuo. The formed residue was dissolved in $25 \mathrm{ml}$ of dry methanol; sulphur $\left(\mathrm{S}_{8}, 0.28 \mathrm{~g}\right.$, $1.1 \mathrm{mM}$ ) was added at once and the reaction mixture was stirred for $10 \mathrm{~min}$ at room temperature. Then, the reaction was cooled to $0^{\circ} \mathrm{C}$, cyanamide $(0.37 \mathrm{~g}, 8.84 \mathrm{mM})$ in $5 \mathrm{ml}$ of dry methanol was added slowly in dropwise manner, and the reaction was continued for $5 \mathrm{~h}$ at the same temperature. After completion, the reaction mixture was filtered and concentrated to get the crude TR-04. TR-04 was further chromatographed over silica gel with dichloromethane/methanol $(98: 2)$ as eluent, yielding $67.8 \%$. The purity of the compound was confirmed by TLC using $\mathrm{CHCl}_{3} /$ $\mathrm{CH}_{3} \mathrm{OH}\left[(95: 5) ; R_{f}=0.72\right]$ and NMR spectra; ${ }^{1} \mathrm{H}$ NMR $\left(300 \mathrm{MHz}, \mathrm{DMSO}-\mathrm{d}_{6}\right) \delta=2.30\left(\mathrm{~s}, 3 \mathrm{H}, \mathrm{N}-\mathrm{CH}_{3}\right), 2.43(\mathrm{t}, 2 \mathrm{H}$, $\mathrm{J}=5.4 \mathrm{~Hz}$ ), $2.59(\mathrm{t}, 2 \mathrm{H}, \mathrm{J}=5.4 \mathrm{~Hz}), 3.28(\mathrm{~s}, 2 \mathrm{H}), 6.68(\mathrm{~s}, 2 \mathrm{H}$, $\mathrm{NH}_{2}$ ).

2.6. Molecular Docking Studies. The molecular docking tool, GLIDE (Schrodinger Inc., USA; release 2014-2), was used for 2-amino-5-methyl-4,5,6,7-tetrahydrothiazolo[5,4c]pyridine (TR4) docking studies into 11 $\beta$-HSD1 enzyme binding pocket. The crystal structure of $11 \beta$-HSD1 was obtained from the RCSB protein data bank (PDB ID: 4K1L) [21]. The protein preparation was carried out using the default parameters of "protein preparation wizard," in Maestro 9.8. The active site of the receptor was defined using the default settings of "receptor grid generation." The chemical structure of TR-04 was drawn using ChemBiodraw Ultra 12.0, imported into Maestro and its 3-D structure was prepared by using the default parameters of "Ligprep." The lowest energy conformation of TR-04 was selected for docking studies. The docking was performed using default parameters of "Ligand Docking wizard" with a standard precision (SP) docking mode. The final evaluation is done with the glide score and the single best pose is generated as the output for TR-04. The docking reliability was evaluated by calculating the root mean square deviation (RMSD) between the pose of cocrystallized ligand and the binding pose predicted by the docking protocol. If the RMSD is below $2 \AA[22,23]$, the docking protocol was considered reliable for predicting the binding poses of ligands.

2.7. Adipocyte Cell Culture. The mouse embryonic fibroblast cell line 3T3-L1 (CL-173) that undergoes a preadipose to adipose conversion and expresses the major pathways of glucose and lipid metabolism was obtained from ATCC (Manassas, VA). Cells were routinely passaged every 3-4 days and maintained in high glucose DMEM containing 10\% fetal bovine serum FBS (Life Technologies, Carlsbad, CA) and $1 \%$ penicillin-streptomycin (Fisher Scientific, Pittsburg, PA) at $37^{\circ} \mathrm{C}$ and $5 \% \mathrm{CO}_{2}$, following an established protocol [24] with some modifications. Cells were subcultured into 6-well dishes at a density of $1 \times 10^{5}$ cells/well (day 0 ), changed to fresh DMEM/FBS medium once confluent (day 2), and induced to adipose conversion by subsequently changing to D1 medium (DMEM/FBS, $1 \mu \mathrm{g} / \mathrm{ml}$ insulin, $500 \mu \mathrm{M} 3-$ isobutyl-1-methylxanthine, and $0.25 \mu \mathrm{M}$ dexamethasone) on day 4 and to D2 medium (DMEM/FBS, $1 \mu \mathrm{g} / \mathrm{ml}$ insulin) on day 6. Mature adipocytes were changed to fresh DMEM/FBS medium on day 8 and used for treatments on the same day.

2.8. Measurement of $11 \beta-H S D 1$ Activity in Adipocytes. $11 \beta$ HSD1 bidirectional oxoreductase (conversion of cortisone to active cortisol) and dehydrogenase (conversion of cortisol to inactive cortisone) activities were measured by incubating 3T3-L1 preadipocytes (days 0 and 4) or mature adipocytes (day 8 ) in medium with either $1 \mu \mathrm{M}$ cortisone or cortisol, 
respectively, for $20 \mathrm{~min}$ at $37^{\circ} \mathrm{C}$. After extraction with ethyl acetate and evaporation in vacuo, glucocorticoid concentrations were measured in triplicate by LC-MS in positive mode (Agilent G1312B-1200 series Infinity Quaternary HPLC system coupled with Agilent 6530A Accurate-Mass Quadrupole Time-of-Flight MS with Agilent Jet Stream source). Dry samples were reconstituted with $500 \mu \mathrm{l} 80 \%$ methanol, centrifuged, and filtered, and $5 \mu \mathrm{l}$ was injected onto a Agilent ZORBAX Eclipse Plus C18 column $(3 \times 100 \mathrm{~mm}$, $1.8 \mu \mathrm{m}$ ). A gradient from $30 \%$ acetonitrile in $0.1 \%$ formic acid to $90 \%$ acetonitrile in $0.1 \%$ formic acid was used for HPLC separation. Mass data were acquired with the following parameters: drying gas temperature $300^{\circ} \mathrm{C}$, drying gas flow $7 \mathrm{~L} / \mathrm{min}$, nebulizer pressure $40 \mathrm{psi}$, sheath gas temperature $350^{\circ} \mathrm{C}$, sheath gas flow $10 \mathrm{~L} / \mathrm{min}$, capillary voltage $3500 \mathrm{~V}$, nozzle voltage $500 \mathrm{~V}$, fragmentor voltage $150 \mathrm{~V}$, skimmer voltage $65 \mathrm{~V}$, and octopole RF peak voltage $750 \mathrm{~V}$. Standard curves for compounds of interest were obtained in a linear dynamic range of 10-50,000 pg and used for quantitative analysis. Peak area was determined by Agilent MassHunter Qualitative Analysis (version B.05.00) software. The percent of conversion ratio was calculated as $100-$ [(initial concentration - final concentration)/(initial concentration)] $* 100 \%$ ratio.

TR-01-4 for cell culture studies was dissolved in DMSO as $1000 \mathrm{x}$ stocks and stored at $-20^{\circ} \mathrm{C}$. When indicated, $11 \beta$-HSD1 activity was inhibited by exposure of cells for $2 \mathrm{~h}$ to vehicle control (0.1\% DMSO) or the appropriate TR-01-4 in the dose range of $0.1-100 \mu \mathrm{M}$. Cell viability was estimated using the MTT assay [25] by absorbance read at $570 \mathrm{~nm}$ on a Synergy H1 microplate spectrophotometer (BioTek, Sunnyvale, CA).

2.9. Adipocyte Differentiation and Lipid Accumulation. The 3T3-L1 preadipocytes were induced to adipose conversion as described above (dexamethasone was omitted) and treated with $1 \mu \mathrm{M}$ cortisone and $0-10 \mu \mathrm{M}$ TR-01-4 throughout differentiation. Cells were stained with Oil red $\mathrm{O}$ on day 8 to visualize differentiated adipocytes and quantify lipid accumulation following an established protocol [24] with some modifications. After medium removal, cells were washed twice with ice-cold PBS and fixed in 10\% neutral buffered formalin at room temperature for $10 \mathrm{~min}$. Cells were then washed twice with ice-cold PBS and stained with 1\% Oil red $\mathrm{O}$ in isopropanol, diluted 3:2 in PBS, for $1 \mathrm{~h}$ at room temperature. Following two additional PBS washes, fresh PBS was added to cover the cell surface and prevent dehydration. Cells were photographed at 40x magnification using EVOS FL Cell Imaging System (Thermo Fisher Scientific, Waltham, MA). Lipid-bound Oil red $\mathrm{O}$ stain was eluted by $30 \mathrm{~min}$ incubation with isopropanol and quantified by absorbance read at $520 \mathrm{~nm}$ on a Synergy H1 spectrophotometer (BioTek).

2.10. RNA Extraction and Gene Expression by qPCR. The total RNA was isolated from cells using TRIzol reagent (Life Technologies) following the manufacturer's instructions. RNA was quantified using Synergy H1/Take 3 plate setup (BioTek). The cDNAs were synthesized using $2 \mu \mathrm{g}$ of RNA for each sample using high-capacity cDNA Reverse Transcription kit (Life
Technologies), following the manufacturer's protocol on an ABI GeneAMP 9700 (Life Technologies).

The resulting cDNA was amplified in duplicate by realtime quantitative PCR (qPCR) using SYBR green PCR Master Mix (Life Technologies). To avoid interference due to genomic DNA contamination, only intron-overlapping primers were selected using the Primer Express version 2.0 software (Applied Biosystems, Foster City, CA) as follows: $\beta$-actin (housekeeping gene), forward primer: $5^{\prime}$-AAC CGT GAA AAG ATG ACC CAG AT-3', reverse primer: $5^{\prime}$-CAC AGC CTG GAT GGC TAC GT-3'; adiponectin (AdiQ), forward primer: $5^{\prime}$-TGT TCC TCT TAA TCC TGC CCA-3', reverse primer: $5^{\prime}$-CCA ACC TGC ACA AGT TCC CTT$3^{\prime}$; leptin (Lep), forward primer: 5'-GAG ACC CCT GTG TCG GTT C-3', reverse primer: 5' -CTG CGT GTG TGA AAT GTC ATT-3'; glucose transporter type 4 (GLUT4), forward primer: $5^{\prime}$-CAG CTC TCA GGC ATC AAT-3', reverse primer: $5^{\prime}$-TCT ACT AAG AGC ACC GAG-3'; fatty acid synthase (FAS), forward primer: $5^{\prime}$-GGC ATC ATT GGG CAC TCC TT-3', reverse primer: $5^{\prime}$-GCT GCA AGC ACA GCC TCT CT-3'; hormone sensitive lipase (HSL), forward primer: $5^{\prime}$-CCA AGT GTG TGA GCG CCT ATT3', reverse primer: $5^{\prime}$-CAC GCC CAA TGC CTT CTG3'; lipoprotein lipase (LPL), forward primer: $5^{\prime}-\mathrm{CTG}$ AAA GTG AGA ACA TTC CCT TCA-3', reverse primer: $5^{\prime}$-CCG TGT AAA TCA AGA AGG AGT AGG TT-3'; peroxisome proliferator activated receptor (PPAR- $\gamma$ ), forward primer: $5^{\prime}$ GCC CTT TGG TGA CTT TAT GGA-3', reverse primer: $5^{\prime}$-GCA GCA GGT TGT CTT GGA TG-3'; and fatty acid binding protein 4 (aP2), forward primer: $5^{\prime}$ - TCA CCT GGA AGA CAG CTC CT-3', reverse primer: $5^{\prime}$ - AAT CCC CAT TTA CGC TGA TG'. qPCR amplifications were performed on an ABI 7500 Fast real-time PCR (Life Technologies). Cycle conditions were $50^{\circ} \mathrm{C}$ for $2 \mathrm{~min}, 95^{\circ} \mathrm{C}$ for $10 \mathrm{~min}$, and then 40 cycles at $95^{\circ} \mathrm{C}$ for $15 \mathrm{~s}$ and $60^{\circ} \mathrm{C}$ for $1 \mathrm{~min}$. mRNA expression was analyzed using the $\Delta \Delta \mathrm{CT}$ method [26] and normalized with respect to the expression of the $\beta$-actin using $\mathrm{ABI}$ 7500 Fast System SDS Software v1.3.0 (Life Technologies). Amplification of specific transcripts was further confirmed by obtaining dissociation (melting) curve profiles with 1 cycle of $1 \mathrm{~min}$ at $95^{\circ} \mathrm{C}, 30 \mathrm{~s}$ at $55^{\circ} \mathrm{C}$, and $30 \mathrm{~s}$ at $95^{\circ} \mathrm{C}$.

2.11. Statistical Analysis. Statistical analyses were performed using Prism 6.0 (GraphPad Software, San Diego, CA). Data were reported as means \pm SEM and analyzed by oneway ANOVA or two-tailed Student's $t$-test, as appropriate. ANOVA post hoc analyses of differences between individual experimental groups were made using Dunnett's multiple comparison tests. Significance was set at $p<0.05$.

\section{Results}

3.1. Synthesis of Tetrahydrothiazolopyridine Derivatives and Molecular Docking Simulations. The molecular docking studies were performed to understand the molecular interactions between TR-0 4 and 11 $\beta$-HSD1 enzyme. First, the reliability of the docking protocol was determined by RMSD calculation between the poses of cocrystallized ligand and its docked conformation. The superimposition of cocrystallized ligand 


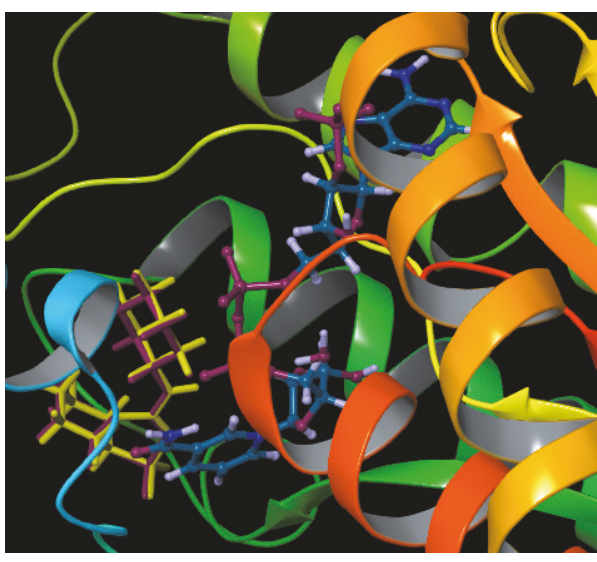

(a)

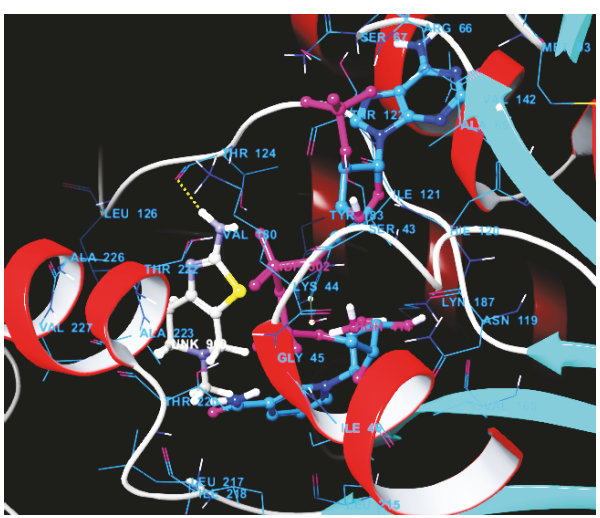

(c)

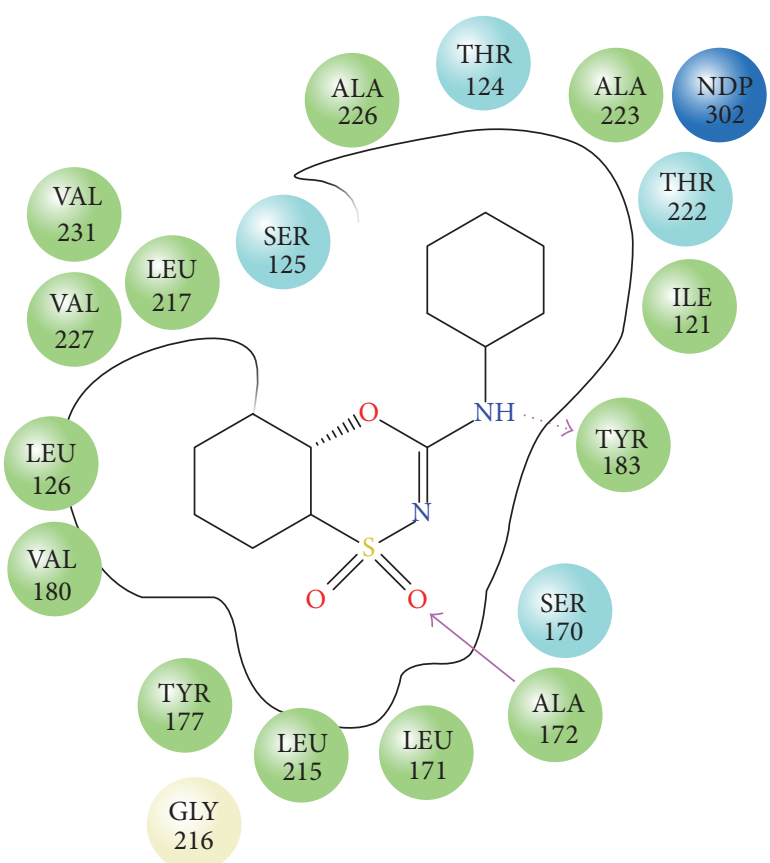

(b)

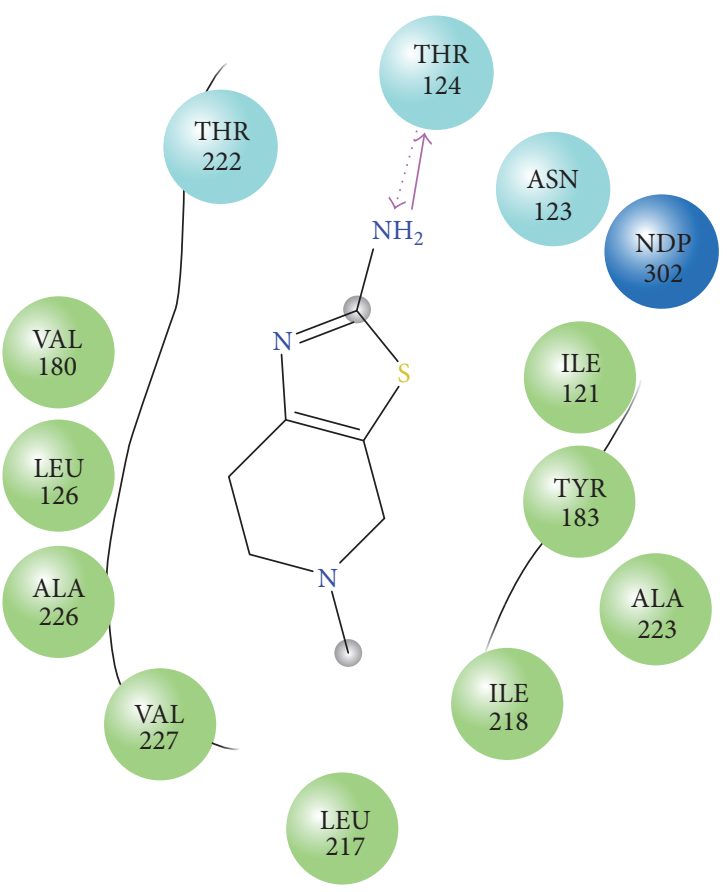

(d)

FIGURE 1: Binding modes of native ligand and TR-04 in the X-ray crystal structure of 11 $\beta$-HSD1 (PDB ID: 4K1L). (a) Superimposition of the poses of cocrystallized native ligand (shown in yellow colored tube representation) with its binding conformation (shown in maroon colored tube representation). (b) The interactions between inbound ligand and amino acid residues of binding pocket (4K1L). (c) The pose of TR04 (shown in ball-and-stick representation). (d) The interactions between TR-04 and amino acid residues of binding pocket (4K1L). Green colored circles indicate hydrophobic amino acid residues; blue colored circles indicate polar amino acid residues.

and its docked pose along with its interactions with receptor is shown in Figure 1. The RMSD was found to be 0.158 indicating the docking protocol used in this study is appropriate for reliable prediction of docking pose of TR-04. Its molecular interactions with amino acid residues of the binding pocket (PDB ID: 4K1L) were similar to those of inbound ligand. The binding pose of TR-04 and its molecular interactions with amino acid residues of binding pocket, facilitating its 
<smiles>Nc1nc2c(s1)CN(Cc1ccccc1)CC2</smiles>

1<smiles>Nc1nc2c(s1)CNCC2</smiles>

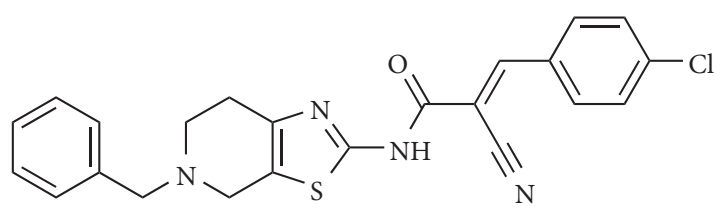

2<smiles>CN1CCc2nc(N)sc2C1</smiles>

FIGURE 2: Chemical structure of tetrahydrothiazolo[5,4-c]pyridine-2-amine (TR-01) and its derivatives (TR-02-4) used in this study.

binding (docking score $=-5.924 \mathrm{Kcal} / \mathrm{mol}$; glide score $=$ $-6.398 \mathrm{Kcal} / \mathrm{mol})$, is shown in Figure 1 . The $-\mathrm{NH} 2$ group of TR-04 forms hydrogen bonding with THR-124 while tetrahydrothiazolopyridine ring occupies the hydrophobic pocket containing ILE-121, THR-183, ALA-223, ILE-218, LEU-217, VAL-227, ALA-226, LEU-126, and VAL-180. The docking results demonstrated possible broad and tight interactions between TR-04 and amino acid residues of $4 \mathrm{~K} 1 \mathrm{~L}$ binding pocket and this may result in potent activity of TR-04. The docking studies provided insights into further modification of TR-04 to develop analogues with more potent activity. Based on these observations, we synthesized Nunsubstituted and $\mathrm{N}$-substituted tetrahydrothiazolopyridine derivatives TR-01-4 (Figure 2). The substitution is based on the requirement of secondary amine $(\mathrm{NH})$ group and/or primary amine (NH2) group for preserving biological activity as well as pharmacokinetic stability of these analogues. The detailed synthetic routes to each compound and their characterization are summarized in Supplementary Material, available online at https://doi.org/10.1155/2017/3182129.

3.2. 11 3 -HSD1 Activity in 3T3-L1 Adipocytes. Undifferentiated confluent 3T3-L1 cells showed a small amount of the $11 \beta$-HSD1 oxoreductase activity ( $8 \%$ of cortisone to cortisol conversion in $2 \mathrm{~h}$ ), while the $11 \beta$-HSD1 dehydrogenase activity (i.e., cortisol to cortisone conversion) was negligible in preadipocytes. As adipocyte differentiation progressed from day 0 to day 4 , we observed a steady increase in $11 \beta$-HSD1 activity. Near-complete adipogenic differentiation (day 8) was associated with a significant increase in the oxoreductase activity with up to $48 \%$ cortisone to cortisol conversion after mature adipocytes were incubated with $1 \mu \mathrm{M}$ of steroid for $2 \mathrm{~h}$ (Figure 3 , black bars). The $11 \beta$-HSD1 dehydrogenase activity remained relatively low throughout the differentiation process and reached maximum $6 \%$ cortisol to cortisone oxidation on day 8 following the induction of adipogenesis (Figure 3, open bars). As $11 \beta$-HSD1 dehydrogenase activity was minimal in these cells, the next set of experiments focused on $11 \beta$-HSD1 oxoreductase activity as the main measure of thiazolopyridine-induced inhibition of $11 \beta$-HSD1.
Bidirectional 11 $\beta$-HSD1 activity

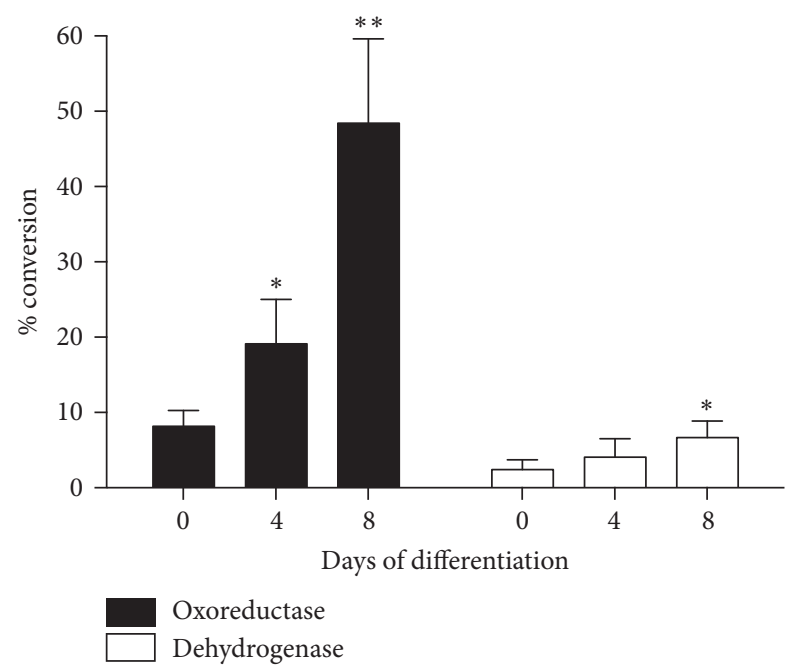

FIGURE 3: Bidirectional oxoreductase (conversion of cortisone to active cortisol, black bars) and dehydrogenase (conversion of cortisol to inactive cortisone, open bars) activity of the $11 \beta$-HSD1 enzyme in 3T3-L1 adipocytes. Cells were grown to confluence and differentiated into adipocytes by day 8 of the treatment. Cells were incubated in DMEM containing cortisone or cortisol $(1 \mu \mathrm{M})$ for $20 \mathrm{~min}$ and the respective metabolites/conversion ratios were measured by LC-MS. Data are the mean \pm SEM $(n=3) .{ }^{*} p<0.05$ and ${ }^{* *} p<0.01$ versus vehicle by Dunnett's test subsequent to oneway ANOVA.

\subsection{Tetrahydrothiazolopyridine Derivatives Inhibit 11 $\beta$-HSD1.} $11 \beta$-HSD1 oxoreductase assays in mature adipocyte cells supplemented with $1 \mu \mathrm{M}$ cortisone for $2 \mathrm{~h}$ showed significant reduction of the oxoreductase activity following incubation with $0.1-100 \mu \mathrm{M}$ of TR-01-4. Parent pharmacophore TR-01 showed moderate efficacy at inhibiting $11 \beta$-HSD1 oxoreductase in a dose-dependent manner (Figure 4(a)). Addition of benzyl group at 5 th position and 4 -chloro- $\alpha$-cinnamoyl moiety at 2 nd position in TR-02 increased $11 \beta$-HSD1 potency as compared to the original molecule TR-01. Unsubstituted TR03 , on the other hand, exhibited decreased inhibitory activity 


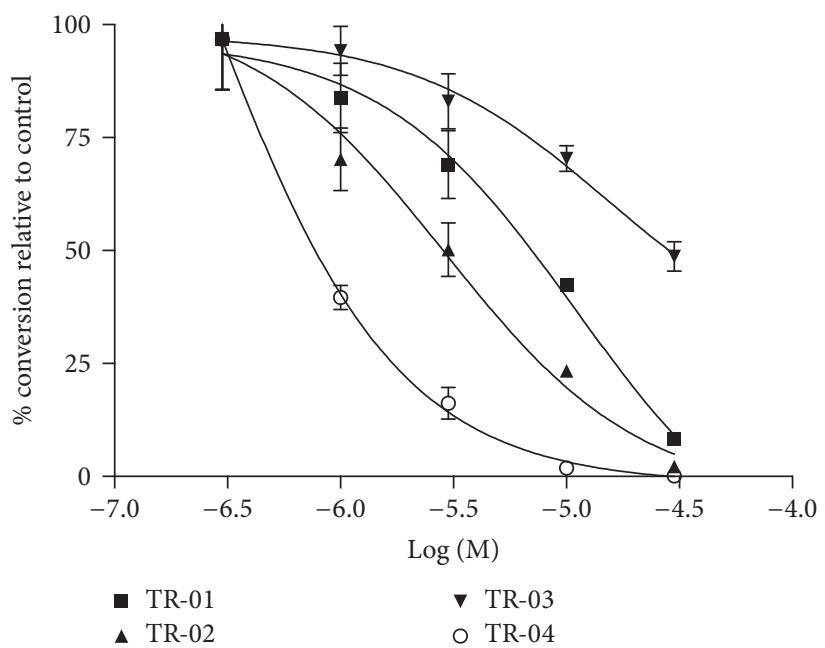

(a)

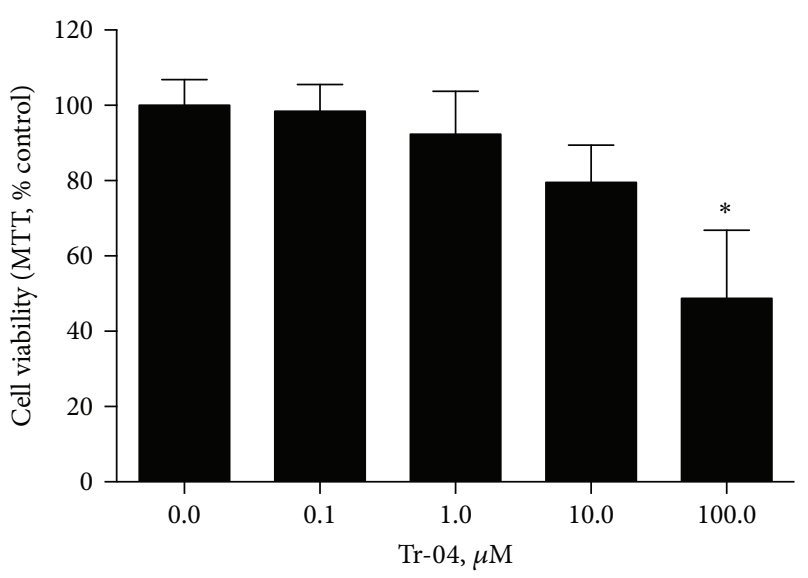

(b)

FIGURE 4: Tetrahydrothiazolopyridine derivatives TR-01-4 inhibited 11 $\beta$-HSD1 oxoreductase activity in the mature 3T3-L1 adipocytes. Cells were treated for $2 \mathrm{~h}$ with $0-100 \mu \mathrm{M}$ of the test compounds and incubated in DMEM containing cortisone $(1 \mu \mathrm{M})$ for $20 \mathrm{~min}$. The resulting metabolite/conversion ratios were measured by LC-MS. Data are the mean \pm SEM $(n=3) .{ }^{*} p<0.05$ versus vehicle by Dunnett's test subsequent to one-way ANOVA.

for $11 \beta$-HSD1. In order to understand the disparity between TR-02 and TR-03, a methyl analogue TR-04 was synthesized. Treatment with TR-04 resulted in a total inhibition of $11 \beta$ HSD1 oxoreductase activity when tested at the concentrations of $>10 \mu \mathrm{M}$ with a corresponding $\mathrm{IC}_{50}$ value of $0.095 \mu \mathrm{M}$. No cytotoxicity was observed in MTT assay at concentrations lower than $10 \mu \mathrm{M}$ for TR-04 (Figure 4(b)).

\subsection{Adipogenesis in 3T3-L1 Cells Incubated with Tetrahy-} drothiazolopyridine Derivatives. 3T3-L1 cells differentiated for 8 days with $1 \mu \mathrm{M}$ cortisone (instead of $0.25 \mu \mathrm{M}$ dexamethasone used in the standard adipogenesis protocols) showed increased $11 \beta$-HSD1 reductase activity of $22.4 \pm$ 9.4\% cortisone to cortisol conversion, a 2 -fold decrease over the standard differentiation protocol (Figure 5(a)). Similarly, cortisone-induced adipocytes expressed higher levels of $11 \beta$ HSD1 mRNA (11.1-fold versus control, $p<0.01$ ) that also did not reach $11 \beta$-HSD1 mRNA levels observed after dexamethasone-stimulated differentiation (20.2-fold versus control, $p<0.001$, Figure 5(b)). The change in adipogenesis and lipid accumulation was quantified through staining the cells with Oil red $\mathrm{O}$ after 8 days of differentiation. A marked increase in the number of red-stained cells was observed in samples differentiated with dexamethasone (39.0-fold versus control, $p<0.001)$ or cortisone (13.3-fold versus control, $p<0.01)$ (Figure 5(c)).

Coincubation with $0.1-10 \mu \mathrm{M}$ compounds TR-01-4 abolished these effects to a various extent. 3T3-L1 adipocytes differentiated with cortisone and TR-04 at doses as low as $100 \mathrm{nM}$ had significantly lower $11 \beta$-HSD1 mRNA levels (0.6fold versus cortisone alone, $p<0.05$, Figure $5(\mathrm{~d}))$ and lipid content $(54.8 \%$ of cortisone alone, $p<0.05$, Figure $5(\mathrm{e}))$. At highest concentration tested, compound 4 nearly abolished $11 \beta$-HSD1 oxoreductase activity (Figure 5(d)) and suppressed adipogenesis and lipid accumulation in cortisone-stimulated adipocytes (Figure 5(d) and 5(e)). Size and degree of lipid droplets accumulation in the presence of the different concentrations of TR-04 $(0-10 \mu \mathrm{M})$ indicated dose-dependent suppression of adipogenesis in response to treatment with thiazolopyridine derivatives (Figure 5(f)).

3.5. Gene Expression of Adipogenic and Insulin Sensitivity Markers. 3T3-L1 cells differentiated for 8 days in the presence of cortisone showed increased expression of markers of lipid metabolism (FAS, HSL, and LPL), insulin signaling (GLUT4), adipocyte function (Lep), and differentiation (PPAR- $\gamma$, aP2); however, the levels of adiponectin (AdiQ) cytokine that regulates energy metabolism and insulin sensitivity were drastically reduced. Coincubation of 3T3-L1 cells with $100 \mathrm{nM}$ TR-04 normalized mRNA levels of biomarkers of lipid metabolism and adiponectin (1.6-fold versus 0.2 -fold in cortisone-treated cells, $p<0.01)$ but had little effect on expression levels of insulin-inducible GLUT4 transporter (Figure 6). Reduced mRNA levels of HSL and LPL were also observed. This is in agreement with previous studies that showed that HSL knockout mice had lower weight gains and adiposity, likely due to compensatory decrease in the reesterification of fatty acids that results in decreased resynthesis of TAG and increased liberation of fatty acids to the vasculature [27]. LPL expression followed the same pattern, although its connection to adipogenesis was not clear and warrants further investigation.

\section{Discussion}

The present study demonstrated a potent inhibition of the $11 \beta$-HSD1 oxoreductase activity (conversion of inactive cortisone to active cortisol) by tetrahydrothiazolopyridine derivatives in the 3T3-L1 adipocyte cell culture. 11 $\beta$-HSD1 acts as a tissue-specific regulator of cortisol exposure in obesity and 


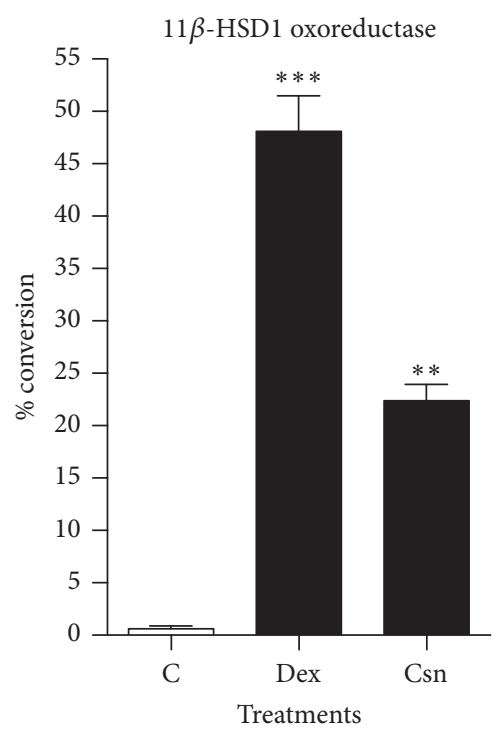

(a)

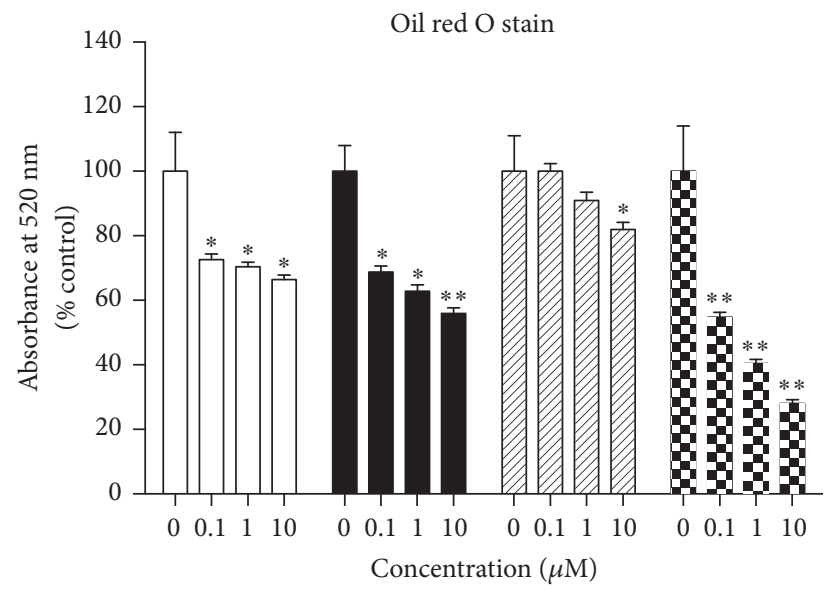

TR-01

TR-02

A TR-04

(d)

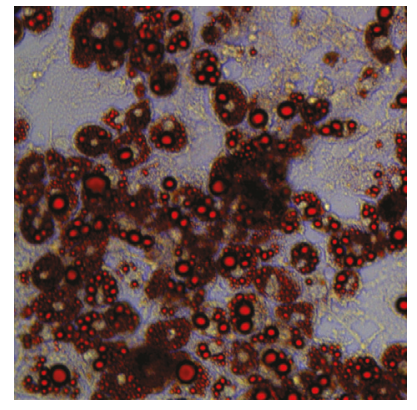

Control

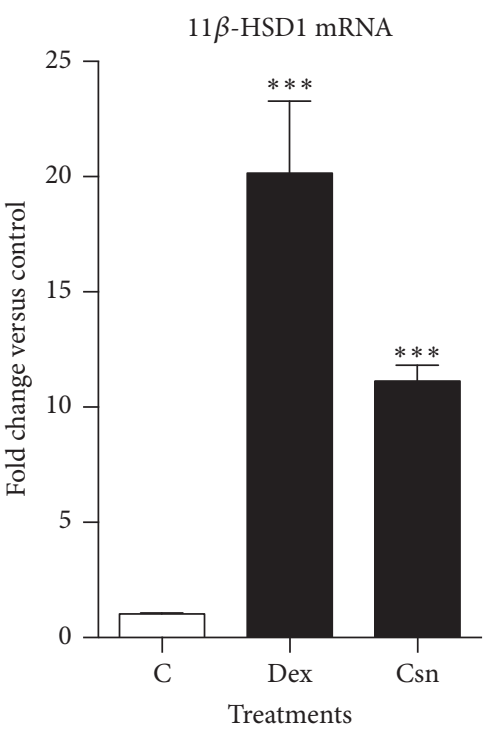

(b)

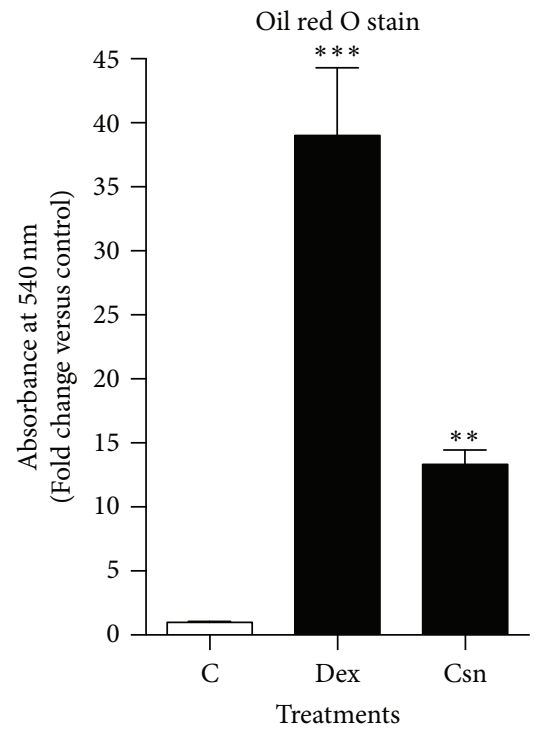

(c)

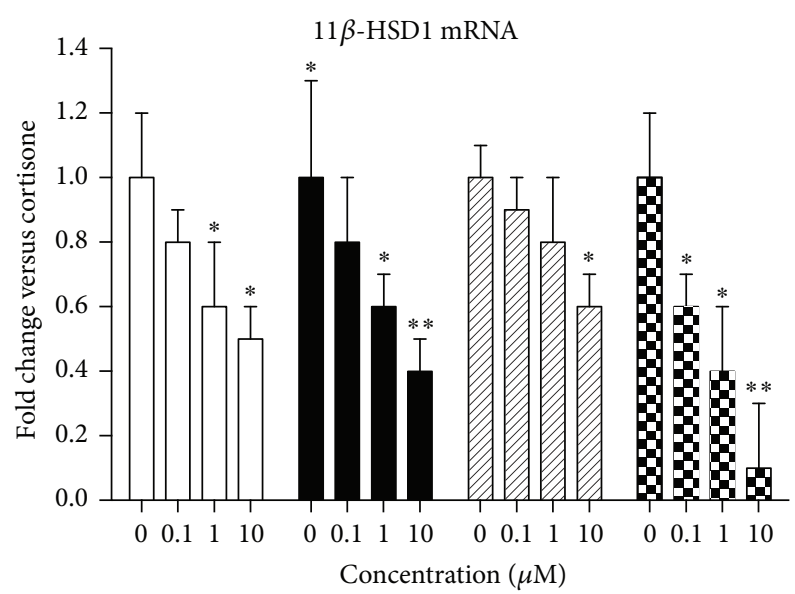

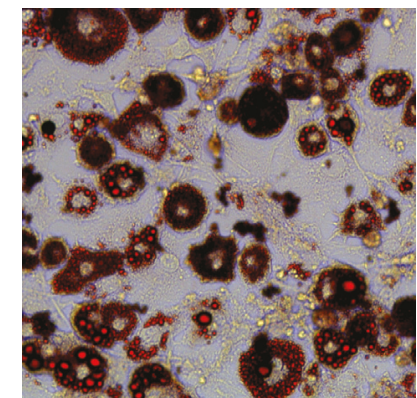

TR-04 $(0.1 \mu \mathrm{M})$

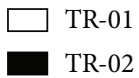

TR-02
ZIA TR-03

\$ TR-04

(e)

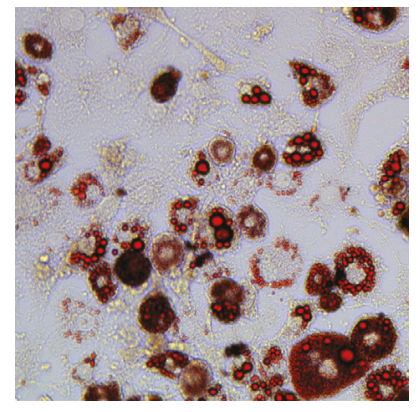

TR-04 $(1 \mu \mathrm{M})$

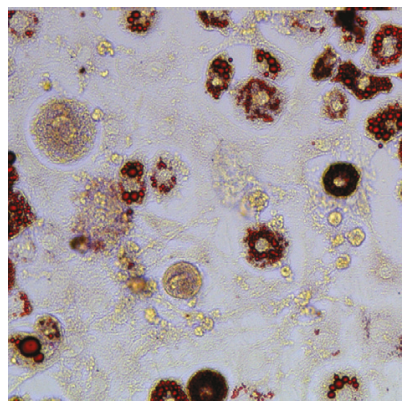

TR-04 $(10 \mu \mathrm{M})$

(f)

FIGURE 5: Tetrahydrothiazolopyridine derivatives TR-01-4 reduced adipogenesis in the 3T3-L1 adipocytes in a dose-dependent manner. Adipocyte differentiation in the presence of $1 \mu \mathrm{M}$ cortisone (Csn) was half less efficient than standard $0.25 \mu \mathrm{M}$ dexamethasone (Dex) induction as evident from induction of the (a) 11 $\beta$-HSD1 activity, (b) 11 $\beta$-HSD1 expression, or (c) lipid accumulation. Dosing of cortisone-treated adipocytes with $0-10 \mu \mathrm{M}$ of TR-01-4 further decreased (d) lipid accumulation as quantified with Oil red O staining and (e) $11 \beta$-HSD1 mRNA levels as measured by qPCR. (f) Oil red O staining of adipocytes differentiated with different concentrations of TR-04 for 8 days. Data are the mean $\pm \operatorname{SEM}(n=3),{ }^{*} p<0.05,{ }^{* *} p<0.01$, and ${ }^{* * *} p<0.001$ versus vehicle control by Dunnett's test subsequent to one-way ANOVA. 
TR-04 (100 nM)
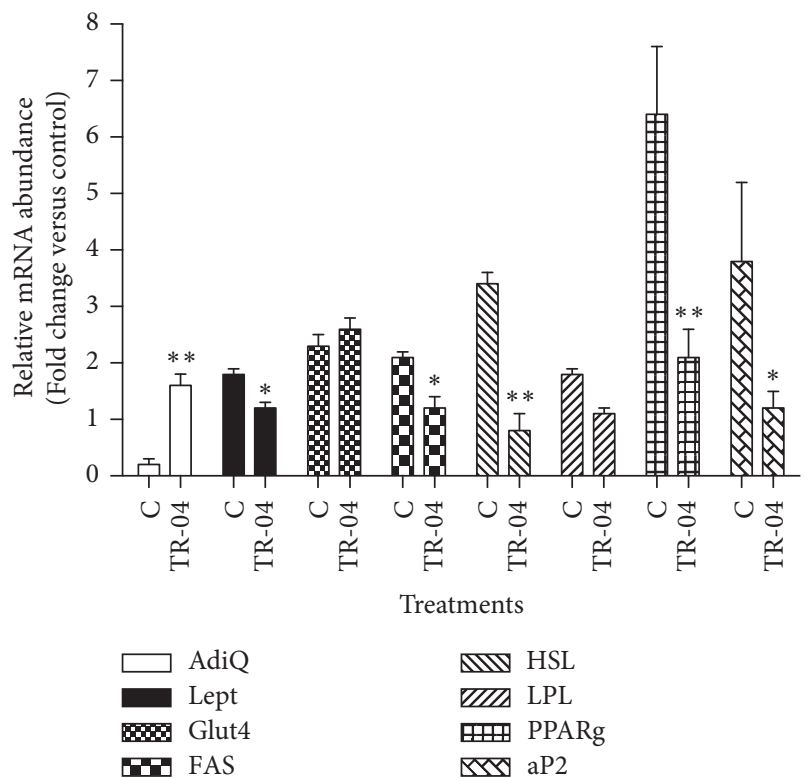

$$
\begin{aligned}
& \text { HSL } \\
& \text { mII LPL } \\
& \text { PPARg } \\
& \text { aP2 }
\end{aligned}
$$

FIGURE 6: Effect of tetrahydrothiazolopyridine derivative TR-04 on the expression levels of adipocyte genes associated with lipid metabolism and insulin resistance. Adipocytes were differentiated in the presence of $1 \mu \mathrm{M}$ cortisone and $100 \mathrm{nM}$ of TR-04 and extracted with TRIzol for mRNA measurements by qPCR. Data are the mean \pm SEM $(n=3)$, normalized with respect to the expression of the $\beta$-actin of undifferentiated control cells. ${ }^{*} p<0.05$ and ${ }^{* *} p<0.01$ versus vehicle control by two-tailed Student's $t$-test.

type 2 diabetes and presents an attractive therapeutic strategy to alleviate multiple complications in patients with metabolic syndrome and excess weight. As expected, undifferentiated 3T3-L1 preadipocytes showed low levels of both 11 $\beta$-HSD1 oxoreductase and dehydrogenase activity due to bidirectional nature of the $11 \beta$-HSD1 enzyme. $11 \beta$-HSD1 is a lower-affinity $\operatorname{NADP}(\mathrm{H})$-dependent enzyme that acts as oxoreductase that regenerates active glucocorticoids from their inactive ketoglucocorticoid precursors in key metabolic tissues [7]. The opposing dehydrogenase activity of $11 \beta$-HSD1 (conversion of cortisol to cortisone) becomes evident only in cell culture and tissue homogenates or upon purification due to decrease of ER luminal cofactor NADP $(\mathrm{H})$ generated by hexose6-phosphate dehydrogenase [8]. Mature 3T3-L1 adipocytes exhibited an expected switch predominantly to $11 \beta$-HSD1 oxoreductase activity [28] by day 8 of differentiation.

TR-02 and TR-0 4 inhibited $11 \beta$-HSD1 oxoreductase activity with $\mathrm{IC}_{50}$ values of $1.8 \mu \mathrm{M}$ and $0.095 \mu \mathrm{M}$, respectively. Incubation of cells with $0.1 \mu \mathrm{M}-10 \mu \mathrm{M}$ significantly decreased cortisone-induced lipid accumulation in adipocytes and suppressed 11 $\beta$-HSD1 mRNA expression in these cells. In rodents, an application of selective $11 \beta$-HSD1 inhibitor adamantyl triazole improved lipid metabolism and reduced body weight and the progression of atherosclerosis [21]. In humans, the situation is less clear as $11 \beta$-HSD1 overexpression was described only in subcutaneous, but not omental adipose tissue [22]. It is not clear if tetrahydrothiazolopyridine derivatives TR-02 and TR-04 used in this study reduced adipogenesis across all adipose tissue depots, or this effect was limited to the cutaneous lineages similar to the 3T3L1 adipocytes used in this study. Further preclinical studies are needed to explore this regulation and its application to metabolic phenotypes. However, pharmacological activity of TR-04 in vitro compared favorably to salicylates that reduced $11 \beta$-HSD1 mRNA levels in fully differentiated human SGBS adipocytes in the dose range of $10-100 \mu \mathrm{M}$ [17].

We also demonstrated that reduced adipogenesis data was consistent with changes in expression of key adipogenic genes associated with lipid metabolism and insulin resistance. Simultaneous increase in adiponectin and decrease in leptin expression suggested that treatment with TR-02 and TR-04 might be effective at improving regulation of insulin resistance and energy homeostasis in obese subjects [23]. At the same time, the observed reduction in the levels of FAS, HSL, and LPL in tetrahydrothiazolopyridine-treated adipocytes indicated reduced deposition of fatty acids in adipose cells. This finding was in a total agreement with Oil red O staining that quantifies the presence of fat or lipids in adipocytes.

\section{Conclusions}

Taken together, our findings suggested that tetrahydrothiazolopyridine derivatives TR- 02 and TR- 04 are the strong $11 \beta$ HSD1 inhibitors and attractive preclinical candidates for the treatment of obesity and type 2 diabetes mellitus.

\section{Conflicts of Interest}

The authors declare that there are no conflicts of interest regarding the publication of this paper.

\section{Acknowledgments}

This work was supported in part by Exploratory Research Grant Scheme, Ministry of Education, Malaysia, Grant ERGS/1/2013/SKK02/IMU/03/1; International Medical University Seed Grant IMU 263/2012; NCSU Office of International Affairs Grant 2013-1705; and the Cell Culture and Phenotyping Core of the Plants for Human Health Institute, North Carolina State University. The authors would like to thank Mr. Selvam Paramasivan (India) for helping with NMR and mass spectral data.

\section{References}

[1] World Health Organization, Action Plan for the Global Strategy for the Prevention and Control of Noncommunicable Diseases, WHO Press, Geneva, Switzerland, 2008.

[2] C. D. Fryar, M. D. Carroll, and C. L. Ogden, Prevalence of Overweight, Obesity, and Extreme Obesity among Adults: United States, Trends 1960-1962 through 2009-2010, National Center for Health Statistics, Hyattsville, Md, USA, 2012.

[3] Institute of Public Health, Prevalence of Non Communicable Diseases and Nutritional Status of Malaysian Adults, National Health and Morbidity Survey, 2011.

[4] M.-J. Lee, P. Pramyothin, K. Karastergiou, and S. K. Fried, "Deconstructing the roles of glucocorticoids in adipose tissue 
biology and the development of central obesity," Biochimica et Biophysica Acta (BBA)-Molecular Basis of Disease, vol. 1842, no. 3, pp. 473-481, 2014.

[5] B. R. Walker, "Cortisol-cause and cure for metabolic syndrome?” Diabetic Medicine, vol. 23, no. 12, pp. 1281-1288, 2006.

[6] E. Rask, T. Olsson, S. Söderberg et al., "Tissue-specific dysregulation of cortisol metabolism in human obesity," The Journal of Clinical Endocrinology and Metabolism, vol. 86, no. 3, pp. 14181421, 2001.

[7] G. Valsamakis, A. Anwar, J. W. Tomlinson et al., "11 $\beta$-hydroxysteroid dehydrogenase type 1 activity in lean and obese males with type 2 diabetes mellitus," The Journal of Clinical Endocrinology and Metabolism, vol. 89, no. 9, pp. 4755-4761, 2004.

[8] N. Draper, E. A. Walker, I. J. Bujalska et al., "Mutations in the genes encoding $11 \beta$-hydroxysteroid dehydrogenase type 1 and hexose-6-phosphate dehydrogenase interact to cause cortisone reductase deficiency," Nature Genetics, vol. 34, no. 4, pp. 434439, 2003.

[9] Y. Kotelevtsev, M. C. Holmes, A. Burchell et al., "11 $\beta$-Hydroxysteroid dehydrogenase type 1 knockout mice show attenuated glucocorticoid-inducible responses and resist hyperglycemia on obesity or stress," Proceedings of the National Academy of Sciences of the United States of America, vol. 94, no. 26, pp. 14924-14929, 1997.

[10] N. M. Morton, M. C. Holmes, C. Fiévet et al., "Improved lipid and lipoprotein profile, hepatic insulin sensitivity, and glucose tolerance in $11 \beta$-hydroxysteroid dehydrogenase type 1 null mice," The Journal of Biological Chemistry, vol. 276, no. 44, pp. 41293-41300, 2001.

[11] H. Masuzaki, J. Paterson, H. Shinyama et al., "A transgenic model of visceral obesity and the metabolic syndrome," Science, vol. 294, no. 5549, pp. 2166-2170, 2001.

[12] D. Sun, M. Wang, and Z. Wang, "Small molecule $11 \beta$-hydroxysteroid dehydrogenase type 1 inhibitors," Current Topics in Medicinal Chemistry, vol. 11, no. 12, pp. 1464-1475, 2011.

[13] M. Hult, H. Jörnvall, and U. C. T. Oppermann, "Selective inhibition of human type $111 \beta$-hydroxysteroid dehydrogenase by synthetic steroids and xenobiotics," FEBS Letters, vol. 441, no. 1, pp. 25-28, 1998.

[14] S. A. Morgan, M. Sherlock, L. L. Gathercole et al., " $11 \beta$ hydroxysteroid dehydrogenase type 1 regulates glucocorticoidinduced insulin resistance in skeletal muscle," Diabetes, vol. 58, no. 11, pp. 2506-2515, 2009.

[15] J. Rosenstock, S. Banarer, V. A. Fonseca et al., "The 11- $\beta$-hydroxysteroid dehydrogenase type 1 inhibitor INCB13739 improves hyperglycemia in patients with type 2 diabetes inadequately controlled by metformin monotherapy," Diabetes Care, vol. 33, no. 7, pp. 1516-1522, 2010.

[16] P. U. Feig, S. Shah, A. Hermanowski-Vosatka et al., "Effects of an 11 $\beta$-hydroxysteroid dehydrogenase type 1 inhibitor, MK0916, in patients with type 2 diabetes mellitus and metabolic syndrome," Diabetes, Obesity and Metabolism, vol. 13, no. 6, pp. 498-504, 2011.

[17] M. Nixon, D. J. Wake, D. E. Livingstone et al., "Salicylate downregulates $11 \beta$-HSD1 expression in adipose tissue in obese mice and in humans, mediating insulin sensitization," Diabetes, vol. 61, no. 4, pp. 790-796, 2012.

[18] A. Aronov, U. P. Bandarage, K. M. Cottrell et al., "Tetrahydrothiazolopyridine inhibitors of phosphaidylinositol 3-kinase," US Patent Application, 2012/0039849A1, 2011.
[19] N. Haginoya, S. Komoriya, K. Osanai et al., "Facile methods for preparation of thiazolopyridine and tetrahydrothiazolopyridine derivatives," Heterocycles, vol. 63, no. 7, pp. 1555-1561, 2004.

[20] A. Gazit, P. Yaish, C. Gilon, and A. Levitzki, “Tyrphostins I: synthesis and biological activity of protein tyrosine kinase inhibitors," Journal of Medicinal Chemistry, vol. 32, no. 10, pp. 2344-2352, 1989.

[21] A. Hermanowski-Vosatka, J. M. Balkovec, K. Cheng et al., "11 $\beta$-HSD1 inhibition ameliorates metabolic syndrome and prevents progression of atherosclerosis in mice," The Journal of Experimental Medicine, vol. 202, no. 4, pp. 517-527, 2005.

[22] L. Alberti, A. Girola, L. Gilardini et al., "Type 2 diabetes and metabolic syndrome are associated with increased expression of $11 \beta$-hydroxysteroid dehydrogenase 1 in obese subjects," International Journal of Obesity, vol. 31, no. 12, pp. 1826-1831, 2007.

[23] P. Kizelsztein, D. Govorko, S. Komarnytsky et al., "20-Hydroxyecdysone decreases weight and hyperglycemia in a dietinduced obesity mice model," American Journal of PhysiologyEndocrinology and Metabolism, vol. 296, no. 3, pp. E433-E439, 2009.

[24] A. Mehra, I. Macdonald, and T. S. Pillay, "Variability in 3T3L1 adipocyte differentiation depending on cell culture dish," Analytical Biochemistry, vol. 362, no. 2, pp. 281-283, 2007.

[25] T. Mosmann, "Rapid colorimetric assay for cellular growth and survival: application to proliferation and cytotoxicity assays," Journal of Immunological Methods, vol. 65, no. 1-2, pp. 55-63, 1983.

[26] J. Winer, C. K. S. Jung, I. Shackel, and P. M. Williams, "Development and validation of real-time quantitative reverse transcriptase-polymerase chain reaction for monitoring gene expression in cardiac myocytes in vitro," Analytical Biochemistry, vol. 270, no. 1, pp. 41-49, 1999.

[27] R. E. Duncan, M. Ahmadian, K. Jaworski, E. Sarkadi-Nagy, and H. S. Sul, "Regulation of lipolysis in adipocytes," Annual Review of Nutrition, vol. 27, pp. 79-101, 2007.

[28] I. J. Bujalska, E. A. Walker, M. Hewison, and P. M. Stewart, "A switch in dehydrogenase to reductase activity of $11 \beta$ hydroxysteroid dehydrogenase type 1 upon differentiation of human omental adipose stromal cells," The Journal of Clinical Endocrinology and Metabolism, vol. 87, no. 3, pp. 1205-1210, 2002. 

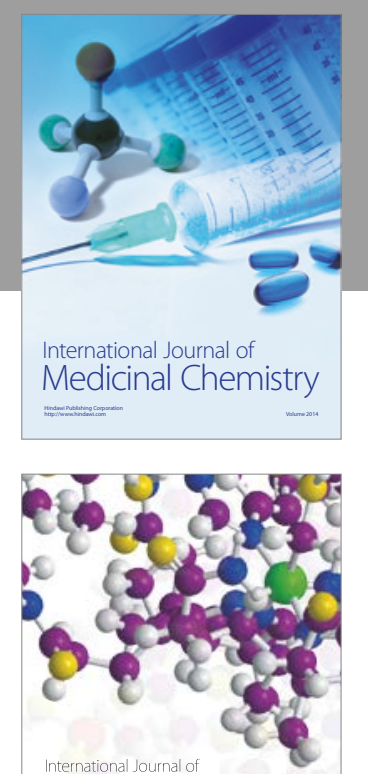

Carbohydrate Chemistry

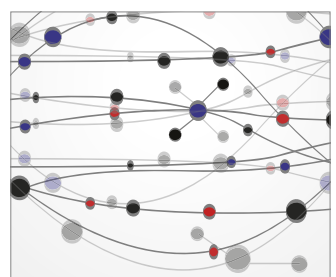

The Scientific World Journal
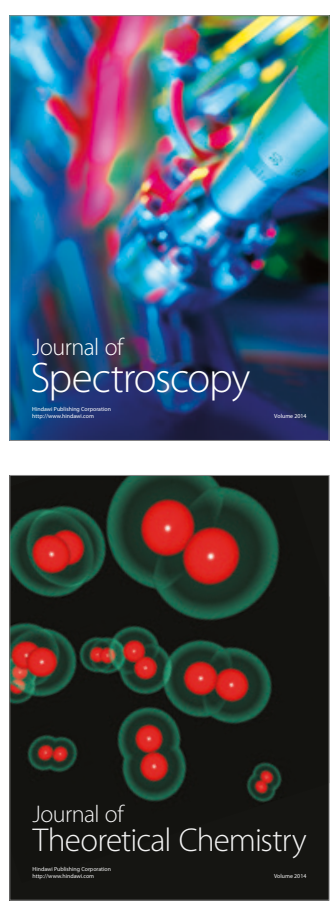
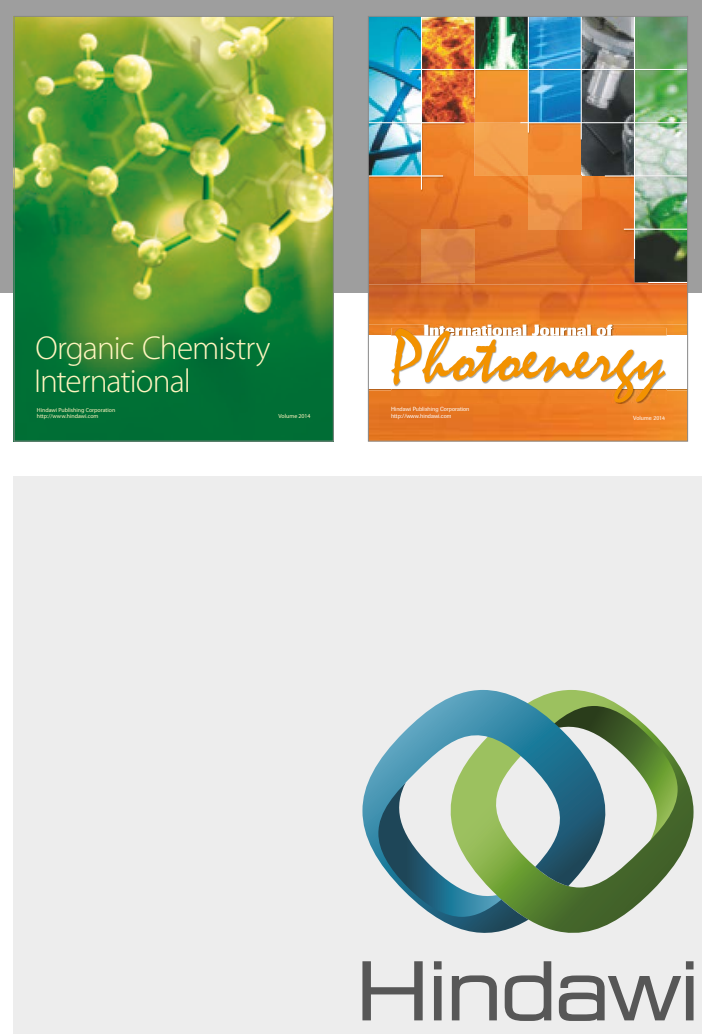

Submit your manuscripts at

https://www.hindawi.com

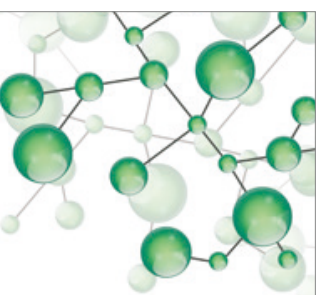

International Journal of

Inorganic Chemistry

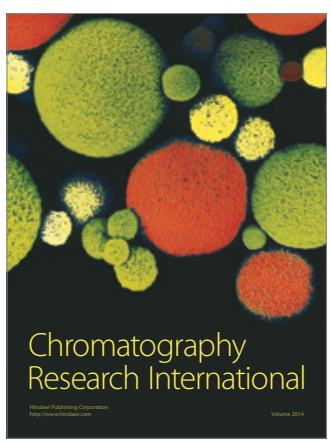

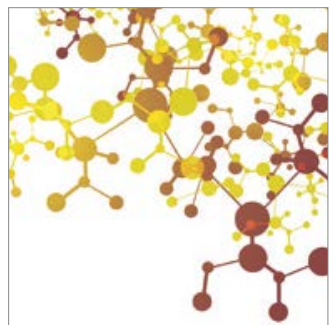

Applied Chemistry
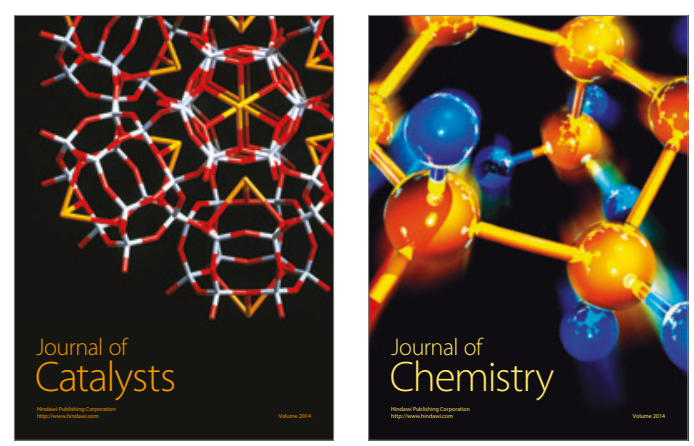
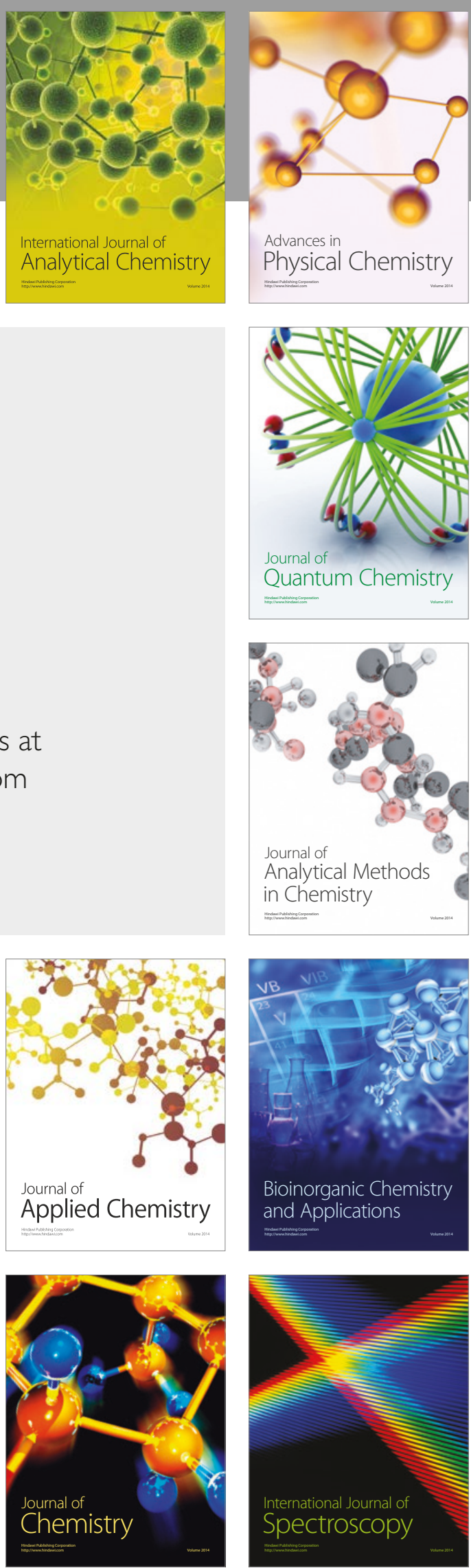